\title{
An analysis of the suitability of students' civic knowledge and disposition in the topic of citizen's rights and obligations
}

\author{
*Dwi Riyanti \\ Institute for Educational Development, Universitas Ahmad Dahlan \\ Jl. Ringroad Selatan, Kragilan, Tamanan, Banguntapan, Bantul, Yogyakarta 55191, Indonesia \\ ${ }^{*}$ Corresponding Author. E-mail: dwiriyanti.ysu@gmail.com
}

Submitted: 10 May 2020 | Revised: 26 May 2020 | Accepted: 23 June 2020

\begin{abstract}
Civic Education has been taught in primary education, but it has not impacted significantly with no strength and function. It is proven by the number of youths who have not understood and implement the citizen right and obligation (bak dan kewajiban warga negara) topic in Civic Education for their daily life. Thus, civic knowledge and civic disposition have not run as expected. This matter has become a great task for Civic Education lecturers to maximize and correlate comprehensively civic knowledge and civic disposition. This study discussed the suitability of civic knowledge and civic disposition in the topic of "Hak dan Kewajiban Warga Negara". This study was descriptive research with a qualitative approach conducted in Universitas Negeri Yogyakarta (UNY), Universitas Ahmad Dahlan (UAD), SMKN 1 Kalikajar (Vocational High School), SMPN 1 Magelang (Junior High School), and SD Kembangsongo (Elementary School) and focused on Civic Education subject by using purposeful sampling. The data were collected through interviews and documentation. The data were then analyzed through the triangulation technique. This study resulted that students in their daily life have not fully implemented both civic knowledge and civic disposition. The matter was caused by students and lecturers of the Civic Education, whereas the subject's topic has met the criteria of the curriculum in the level of Elementary School, Junior High School, and Senior High School/Vocational High School although not all topics were taught in these levels.
\end{abstract}

Keywords: civic knowledge, civic disposition, civic education

How to cite: Riyanti, D. (2020). An analysis of the suitability of students' civic knowledge and disposition in the topic of citizen's rights and obligations. REiD (Research and Evaluation in Education), 6(1), 78-86. doi:https://doi.org/10.21831/reid.v6i1.31621.

\section{Introduction}

Sunarso, Sartono, Dwikusrahmadi, and Sutarini (2016, p. 6) explains the report of the Session of BPUPKI and PPKI stating that education in Indonesia must be able to prepare students to become citizens who have a strong commitment to maintain the Republic of Indonesia unity which has the essence of modern nationalism. It means that in a modern era, the formation of nation and state is based on a sense of nationalism of the people who have a strong determination to build a future with a variety of different populations.
A country that adheres to the concept of democracy will prove the development of the concept of civil society that has a concept of a position to gather the strength of society to maintain the freedom, diversity, and independence of the community against state and government power. Although there is independence, both are having a mutual relationship (Alam, 2014, p. 196). Ferguson, Hume, and Adam Smith began to identify the concept of civil society with a civilized society oriented to the material organization (Jb \& Darmawan, 2016, p. 40). Therefore, to realize 
the civil society concept, a state with a good civic competence is required.

Civic Education has been taught since elementary school education in Indonesia. In addition, citizenship knowledge can be obtained from non-formal education by reading news both from print and electronic media. Therefore, citizenship knowledge is not only theoretically, but also practically looking directly on the current evidence in the scope of citizenship. Even though citizenship knowledge can be obtained through non-formal education, formal education still has a very significant share of students' knowledge of citizenship (Galston, 2007, p. 627).

Currently, Civic Education has not been able to have a significant impact; it is still not functioning properly and powerless, although, in the reformation era, Civic Education demands that it can revitalize itself so that it can carry out its vision and mission. Charles in Print, Ellickson-Brown, and Baginda (1999, pp. 133-135) believes that the contents of Civic Education can be arranged in three models, namely formal curriculum implemented in learning, an informal curriculum that can be implemented in extracurricular activities, and bidden curriculum such as ethical development that can be developed in daily actions. With these three models, it is expected that students can have citizenship knowledge and can internalize it in everyday life.

According to Branson (1999, pp. 8-25), there are three aspects of Civic Education, namely civic knowledge, civic skills, and civic disposition. One of the aspects of Civic Education is civic knowledge. This material/topic is a substance related to rights and obligations that citizens should know it. This must be owned by every individual because it can positively affect and a picture of democratic values in society. When specifically described, the material/topic on citizenship knowledge includes several things, namely knowledge in terms of structure and political system in government, national identity, free and impartial justice, the constitution used, and the values that live in society.

Civic disposition is a citizenship competency. This is a combination of civic knowledge and civic skills. Civic disposition is a component related to a citizen's character in the scope of democracy that can be measured through the level of citizen awareness. This includes how a citizen understands his rights and obligations by complying with applicable laws, thinking critically, expressing opinions, having good morals, being responsible, being a good listener, discipline, and upholding human dignity (Feriandi \& Harmawati, 2018, p. 77). It is also similar to the purpose of national education to develop students' potential to be faithful and devoted the almighty, noble, knowledgeable, skilled, creative, independent, and responsible for a democratic country (Ernawati, Tsurayya, \& Ghani, 2019, p. 21).

Civic disposition in the formal curriculum can play an important role in shaping the character of students. Moreover, this is supported by Law No. 12 of 2012 of Republic of Indonesia on Higher Education in Article 35, Paragraph 3 for which the higher education curriculum must contain compulsory subjects, one of which is Civic Education. Therefore, through this subject, students can get civic knowledge and civic skills so that they can form civic disposition. In addition to the formal curriculum of civic disposition, it can be formed through activities undertaken by students, such as UKM or Unit Kegiatan Mahasiswa (students' extracurricular activities) and state defense training activities for students that have been carried out by Universitas Ahmad Dahlan.

Frailon, Schulz, and Ainley argue that civic disposition research resulted from ICCS on Civic Education situation in five countries such as Indonesia, Hong Kong, Republic of Korea/South Korea, Taiwan, and Thailand, have produced civic knowledge in Indonesia and Thailand on VIII class students is lower as compared to other sample countries in Asia. In addition, there are still many traffic violators derived from students themselves (Ainley, Fraillon, \& Schulz, 2012, p. 3).

This opinion is in line with Wardhani, who states that Operasi Progo Polresta Jogja has cited and reported 977 violators, and 327 are students. Therefore, there are some points for educators to improve students' civic knowledge in order to produce a good civic disposition (Wardhani, 2019). 
According to Setiawan and Suardiman (2018, p. 12), the social attitude can be identified through positive and negative trust in a particular entity's feeling and attitude that has three categories, namely emotional, cognitive, and attitude as it is connected with the previous matter, so that students have not fulfilled themselves in these categories, and that the civic knowledge and civic disposition have not been reached optimally.

The fact indicates that there are still a number of tasks of the lecturers to improvise civic knowledge for students to gain and reach for good civic disposition. As long as the civic disposition has been well developed, the citizens will have good behavior to support their political participation, and that the political system will function proportionally in order to improvise dignity and public's interest (Sunarso et al., 2016, p. 15). Therefore, this study discussed and analyzed the suitability of civic knowledge and civic disposition in the topic of citizen's rights and obligations in the subject of Civic Education.

\section{Method}

This research was a descriptive study that used a qualitative approach. This research aimed to find and analyze the suitability of civic knowledge and civic disposition, especially in the topic of rights and obligations of citizens on students of Universitas Negeri Yogyakarta (UNY) and Universitas Ahmad Dahlan (UAD). This study collected various kinds of data and exploited a time effectively in the study's field (Creswell, 2016, p. 254). The procedures undertaken in this study were interviews and documentation. The interview was conducted since February 15 to April 17, 2020 , with ten different informants as classified into three categories, namely (a) Civic Education expert and Civic Education lecturer, (b) Civic Education teacher both in Elementary/Junior High School/Vocational School, and (c) Five Students at UNY and UAD.

This qualitative study was started by using an assumption as well as interpretation that could form and influence the studied matter (Creswell, 2015, p. 59). In validating the data, the researcher used source triangu- lation that involved different information that could coherently build thematic justification (Creswell, 2016, p. 269). Miles and Huberman (1994, pp. 10-12) stated that the technique of data analysis used data reduction, data display, and conclusion.

This study used a purposeful sampling technique by two considerations in determining the subject of research. The two considerations were the decision to choose the subject of research and the sample's specific strategy (Creswell, 2015, p. 215). Therefore, the researcher chose the specific subject of research to obtain a reflection on a problem that was being investigated, namely the suitability of civic knowledge and civic disposition in the subject of Civic Education for students at UNY and UAD. Based on the criteria, the researcher involved some subjects as informants, namely the expert on Civic Education, lecturer on Civic Education, teacher on Civic Education, and students at UNY and UAD who were enrolled in Civic Education class.

The research was conducted at Universitas Negeri Yogyakarta (UNY), Universitas Ahmad Dahlan (UAD), SMPN 1 Magelang, SMK Negeri 1 Kalikajar, and also SD Negeri Kembangsongo. The reason that the researcher chose the Civic Education subject was to know how far the suitability between civic knowledge and civic disposition in the topic of rights and obligations as well as to identify its relationship to the curriculum of the Elementary School, Junior High School, and Senior High School/Vocational High School. Besides, the reason that the researcher conducted the study at UNY and UAD was to know how far the suitability between civic knowledge and civic disposition in the topic of citizen's rights and obligations in the private university, state university, and Islamic university. SMPN 1 Magelang, SMK Negeri 1 Kalikajar, and SD Negeri Kembangsongo were chosen because the teachers were the alumni of the Civic Education study program at UNY.

To get a clear description and information about the suitability of civic knowledge and civic disposition in tertiary institutions, especially at UNY and UAD as well as the compatibility between subject/course with 
Civic Education curriculum in Elementary/ Junior High School/ Vocational High School, this study determined the researched subject by using a purposive sampling technique. Creswell (2015, p. 217) states that research that used purposeful sampling technique was to determine specific and qualified subjects who could provide an overview of the investigated problem. The followings are the characteristics of the subject based on their roles classification. (1) Two Civic Education experts and Civic Education lecturers were involved in determining the extent of conformity between civic knowledge and four civic disposition in citizens' rights and obligations. (2) Three Civic Education teachers both in elementary/middle school/vocational school were involved in studying the compatibility among subjects in college with the Civic Education curriculum in elementary/middle school/vocational school. (3) Five students at UNY and UAD, who had taken Civic Education subjects to find out the suitability between civic knowledge and civic disposition, were involved.

In collecting data, this study applied two kinds of techniques, namely interview and documentation. The performed interview was a structured interview for which the issues and questions were previously determined. The results of the interview were called primary data obtained from research subjects. Meanwhile, the documentation technique was to support and supplement primary data, namely, the interview. Documentation was taken from data and records related to the compatibility between civic knowledge and civic disposition in the Civic Education subject.

\section{Findings and Discussion}

Civic Knowledge

According to Cogan in Winarno (2013, p. 4), Civic Education is a subject/course that prepares young people to have an active role in the nation's life and state. Civic Education aims to prepare students to become active, critical, rational, and creative in addressing the issue of citizenship. Rosnawati, Kartowagiran, and Jailani (2015, p. 187) also state that critical thinking can ease someone to process and use the information to solve any problem. Besides, the goal of Civic Education is that the younger generation can actively participate as well as intelligently be responsible for social activities in terms of the nation and state (Winarno, 2013, p. 95).

In this study, the learning outcomes are conducted by focusing on one of the aspects of civic knowledge where students can know, understand, and internalize the material/topic in the Civic Education subject. The material/ topic involves the rights and obligations of citizens. Certainly speaking, this is a process of teaching and learning activity that students must achieve because civic knowledge is basically a matter related to rights and obligation that citizens should carry out (Budimansyah, 2010, p. 49).

From an interview on students at UNY and UAD, it was found that they have already known about the rights and obligations of citizens. They have also understood the elements in the rights and obligations as regulated and clearly stipulated in the 1945 Constitution of the Republic of Indonesia. The interview with ADW, a student at the Automotive Study Program of UNY on February 15, 2020, has indicated that he could explain the rights and obligations in detail. In addition, other students could also explain the Articles in the 1945 Constitution of the Republic of Indonesia that regulated Indonesians' rights and obligations.

Citizens are those who live in a certain area and people in relation to the state. In their relation to the state, citizens have obligations to the state, and that the citizens also have rights that must be granted and protected by the state. Citizens' rights are everything that citizens must obtain from the state (government). Obligations are all things that must be carried out by citizens of the state. Rights and obligations of citizens are according to the 1945 Constitution on Citizens' Rights in the Article $27(1,2,3)$ the Article 28 ( $A, B, C, D, E, F, G, H, I, J)$, the Article 29 (2) on the freedom of religion, the Article 30 on Defence and National Security, the Article 31 on Obtaining Education, and Rights and Obligations of Citizens in the Article 27 (1) on establishing the same citizens' rights in law and 
government, and the obligation to uphold the law and government. It is also stipulated in Article 27 (2) on establishing the right of citizens to work and a decent living for bumanity, and finally, in Article 27 (3) on establisbing the rights and obligations of citizens to participate in efforts to defend the state.

The result of the interview indicated that the student understood the mutual relationship between citizens and the government. The mutual relationship means that both citizen and the government have their own rights and obligations. Thus, the rights and obligations as in the 1945 Constitution of the Republic of Indonesia regulate not only citizens' obligations and rights but also the rights and obligations of the state (government). In the same context, a similar opinion was also expressed by FAR (on February 16, 2020) as one of the students at Universitas Ahmad Dahlan, that between citizen and the state, there is a mutual relationship. He added that a right is something a citizen has a freeaccess to perform an action or speak a statement (opinion/argumentation) because he has done his duty as a citizen, whereas the obligetion of citizens is everything that must and a citizen himself do compulsory.

Both interviews have indicated that students from both UNY and UAD have understood the meaning of citizens and the state's rights and obligation. Therefore, civic knowledge competency is achieved. Similarly, civic knowledge has a relationship to what citizens must know. The content of civic knowledge is also related to the compulsory knowledge for which the citizens should recognize and comprehend (Budimansyah, 2010, p. 29).

According to Feriandi and Hermawati, civic knowledge is not only seen from the cognitive aspect, but also from other aspects such as social services and discussions in lectures on the issues of citizenship. Students are also done in doing social services in orphanages and in communities with low economic level. In addition, students have also been accustomed to be told in a class about current topics in the community. Thus, students can explore the civic knowledge they have gained in the subject they have learned (Feriandi \& Harmawati, 2018, p. 78).

\section{Civic Disposition}

Civic disposition is a very basic and essential competency. Civic disposition is considered as the spearhead of the development of civic knowledge and civic skills. Quigley, Buchanan Jr., and Bahmueller (1991, p. 11) explain civic disposition as "...those attitudes and habits of mind of the citizen that are conducive to the healthy functioning and common good of the democratic system". It means that citizens' attitudes and habits are conducive to healthy functioning and the same virtue in a democratic order. Similar to this opinion, Branson (1999, p. 23) states that both public and private characters are important in developing a constitutional democratic system.

Branson (1999, pp. 23-25) strengthens that public and private characters can be described as follows. (1) Becoming an independent member of the community. (2) Being able to fulfill the responsibilities of being a citizen in the economic and political fields. (3) Being able to respect the dignity of all individuals regardless of social status and so on. (4) Being able to actively participate in the affairs of citizenship effectively, responsibly, and also wisely. (5) Being able to develop the function of democracy in a healthy way.

As previously explained, it can be seen that the character (private and public character) of citizenship is very important in the survival of the nation and state. In this case, the researcher examines civic disposition's competence in terms of citizens' rights and obligations. This resulted in both students at Universitas Negeri Yogyakarta and Universitas Ahmad Dahlan having implemented civic disposition in their daily lives, although it is not optimally performed.

As a citizen, I have the right to get appropriate
education services as my choice, and I can get it.
As a citizen, I am obliged to help maintaining
barmony, and that I perform by always adapting
with tolerance against differences, for example
being tolerant in the campus environment;
remembering that the campus consists of a variety
of different religion, culture, ethnicity, and so on.
(An interview with SM on February 16,
2020).

As a citizen, I have the right to get appropriate education services as my choice, and I can get it. As a citizen, I am obliged to help maintaining harmony, and that I perform by always adapting with tolerance against differences, for example being tolerant in the campus environment; remembering that the campus consists of a variety of different religion, culture, ethnicity, and so on. 2020). 
The aforementioned statement indicated that the civic disposition of citizens' rights and obligations has appeared in student's personality by not only claiming rights but also carrying out his obligations as citizens through maintaining tolerance in the campus environment with a diversity of religion, culture, and ethnicity. Thus, any effort to establish students' civic disposition on the material of "citizen's rights and obligations" has been achieved, although not fully performed. The similar result can be also identified through an interview on April 6, 2020 with DA as a student at UNY who stated that taking education in tertiary institution is an implementation that every citizen has the right to receive education, to carry out worship according to religion, to choose their respective religion, and the fulfilment of food and clothing as a form of citizens' right in a decent living, obeying the tax system as a fulfilment of tax and legal obligation, following the Pancasila and Civic Education course as an obligation to defend the country, and avoiding SARA or Suku, Agama, Ras, and Antargolongan (Ethnic, Religion, Race, and Multi-groups) as an implementation of the obligation to respect the rights of others.

The interview also proves another similar result on April 6, 2020, with DCN as a student at UAD, who explains that students have indeed implemented their rights as citizens through participating in public's opinion, such as participating in demonstration activities. Therefore, it can be concluded that not all students have embedded in civic disposition, because there are still the rest of the students who have not implemented their rights and obligations properly.

The Suitability of Civic Knowledge and Civic Disposition in the Material of "Rights and Obligations"

Somantri (2001, p. 116) states that Civic Education is an effort done scientifically and psychologically in providing easy access for students to learn so that the moral internalization of Pancasila and knowledge of citizenship to realize personal integrity and everyday behavior are based on the national education goals. Thus, Civic Education in higher educa- tion is expected to prepare students as young people to participate in the nation's life and state. Students, as the young generation, are given an understanding of national ideals and how to act to overcome problems through Civic Education. Therefore, students can withdraw any decision that is responsible for overcoming private and national problems.

The 1945 Constitution is a foundation of formal values, norms, and moral education in Indonesia and implemented through Civic Education. It is also poured into Law No. 12 of 2012 of Republic of Indonesia on Higher Education in Article 35, which states that universities are required to teach subjects in Religion, Pancasila (five pillars of the nation), Citizenship, and Indonesian both at undergraduate and diploma level. Civic Education in nomenclature is always undergoing a transformation. Initially, it is previously a Civic course, and transformed to be Civic Education course, although there are still a number of topics that are typically citizenship, such as the concept of Pancagatra and Trigatra.

In this context, $\mathrm{S}$ as an expert in Civic Education at UNY stated that after the reformation, the transformation of the nomenclature has changed from Gallantry (manliness) to Civic Education. Although it has undergone a change, there are still typical topics of dignity such as Pancagatra and Trigatra, which indicate that the atmosphere still has an atmosphere and nuance of Gallantry (manliness). Furthermore, $\mathrm{S}$ said:

Although the material of democracy, buman rights, and knowledge on state institutions are included in the Civic Education subject, the metamorphosis of that authority tends to be considered to represent military typology in the current state defence framework. Civic knowledge aspects are related to democracy, human rights, local government in tertiary institutions especially in state universities issued by the General Director of Higher Education in 2004. Because the Civics Education subject in tertiary institutions is still new, it was previously becoming a Gallantry (manliness). The figure is Kunto Wibisono; the development team for the transformation of Civic Education from Gallantry (manliness) in Higher Education. For me, there are actually many things that must be clarified from the epis- 
temology both from the scientific framework and from the scope of activities. On the other hand, building the character of citizenship in the University's Civic Education subject on post-citizenship, we can also see the difference after it was regulated in 2012; when there was a circular from the General Director of Higher Education mentioned that one of the concepts of Law No. 12 of 2012 on Tertiary Education required tertiary institutions to teach a minimum of four compulsory subjects in tertiary and diploma colleges. Those subjects were religion, Indonesian, Pancasila, and Civic Education. (An interview with S on March 9, 2020)

The statement indicates that Civic Education still tends to represent the military typology in the concept of state defense and its civic knowledge aspects related to democracy, human rights, and government. There must also be clarity from the epistemological concept. Another perspective is also given by $\mathrm{C}$ as an expert of Civic Education at UNY on March 9, 2020. He states that to make civic disposition matched to civic knowledge, a theory is not the first priority, but rather to the understanding of citizens concerned that each citizen has to associate for the sake of living in a democratic country.

In addition, $\mathrm{C}$ emphasized that Civic knowledge and civic disposition should be able to develop citizens' intelligence, so that students as young people can stick the values of virtue with a good character. The attitude can be controlled through intelligence, although there are two ways to control attitudes, namely habit (obtained since Early Childhood Education to junior high school) and the level of intelligence understanding of the importance of attitude that compulsory to be realized by high school and college students. He also argued that that civic disposition presently is only introduced to concepts and theories, so it will not be formed at any time. Thus, civic knowledge should gain a high level of understanding than just a theory.

In the view of the material aspects of citizens' rights and obligations, the suitability between civic knowledge and civic disposition is still not fully internalized, although many students actively participate in student's organizations on the campus. This evidence has addressed that they have internalized their rights as citizens of an association (community). In the same context, the interview on March 1, 2020, with HH, as one of the lecturers of Civic Education at UAD stated that the material rights and obligations are appropriate, although students are still not aware of the importance of the material so that any experience in the field is needed.

Civic Education has not been very effective in shaping citizens' character because it still needs to be strengthened with other supplements outside of Civic Education. In line with it, S, another informant being interviewed on March 9, 2020, also stated that there was a need to reorganize the substance of Civic Education subject in higher education with current issues in defending the country, deradicalization, and efforts to minimize intolerance. One of the values built on Civic Education was how to live together and have responsibility for the nation and the state with dynamic challenges.

Further, $\mathrm{S}$ argued that state defense material also had an impression of denying the existing Civics Education models. Defending the state is similar to defending the nationality model by Gallantry (manliness). Any physical activity is how to differentiate it. In this context, the topic of state defense in the National Defense Institute is like revitalizing the spirit of dignity that once exists in the Civic Education subject. It is similar to the view that Civic Education merely reaches the cognitive domain, and there are some studies found in state defense materials in the candidates for civil servants through education and training.

Further, civic knowledge and disposition in the material of rights and obligations have not been fully successful, although it is caused by individual factor. The interview on April 17, 2020, with SYT, a lecturer of Civic Education at UNY, found that civic knowledge and disposition on citizen's rights and obligations were caused by individual factors. It is also reinforced by the opinion of FFH, a lecturer of Civic Education at UNY who stated that the students' factors have become a cause of the entirely appropriateness of civic knowledge and disposition (Resulted from an interview on March 4, 2020). 
Apart from the students' factors', C additionally pointed out that it was influenced by factors of lecturers who did not necessarily have a Civic Education background; and that the lecturers from the graduate program of Civic Education were also similarly considered not to have the same perspective in terms of attitude (Resulted from an interview on March 9, 2020). The attitude perspective has varied, and there should be a powerful test for it. Besides, the course was not conducted intensively. Another weakness was that it was rare for someone to pursue a field of expertise during the course (Resulted from an interview on March 9, 2020). Thus, it is the time for lecturers to be engaged in a truly ingrained field so that they can get more actual and relevant views to be effectively substantive and productive in the development of science.

The compatibility of Civic Education subject in tertiary institutions and elementary/ junior high school/senior high school/vocational high school must also be assessed because the assessment needs to be conducted to verify and validate teachers' competency. On the other hand, TM, a teacher at State Junior High School 1 Magelang and the alumnus of Civic Education at UNY, stated that most were appropriate and in class VII put more emphasis on constitutionality (Resulted from an interview on March 5, 2020). In line with this, WW as a teacher at Kembangsongo Elementary School and alumnus of Civic Education at UNY, also argued that there was conformity even though the curriculum for elementary school still applied for K13 curriculum were elaborated in the form of theme, sub-theme, and basic competency (Resulted from an interview on April 6, 2020).

Based on the interviews, it is identified that most of the assumptions have met the criteria of analysis, although not all materials/ topics obtained from university's lecture have been taught in the elementary/junior high school/senior high school/vocational high school. EP positively confirms this argumentation as a teacher at State Vocational High School 1 Kalikajar that not all materials/ topics obtained from university's lecture have been already taught, and that the teachers have already delivered any material/topic by using a variety of methods, such as Discovery Learning, Project-based Learning, and Problem-based Learning (Resulted from an interview on March 3, 2020).

\section{Conclusion}

The suitability between civic knowledge and disposition in the subject of Civic Education in the topic of "citizen's rights and obligations" has not been fully implemented as expected. This is proven by the fact that the students have understood the mutual relationship between citizens and government, but they have not fully implemented their comprehension into their daily life. A field study like democratic learning is necessary in order that students do not only understand but also implement it.

Apart from the students and lecturers factor, the lecturers of the subject Civic Education do not certainly have the background knowledge on civic education and those who come from the Civic Education study program with a few of attitude and perspective enrichment. This evidence can make civic knowledge, and civic disposition have not been optimally conducted and matched. It means that the Civic Education has not been effective in forming citizenship character for youths, like the supplementary program the candidates for civil servants that are also expected to form the character of the citizen. A study on the suitability of Civic Education in higher education with the curriculum on elementary school, junior and senior high school, and vocational high school has indicated the existence of suitability although not all topics discussed in higher education are previously taught in elementary school, junior and senior high school, and vocational high school.

\section{References}

Ainley, J., Fraillon, J., \& Schulz, W. (2012). ICCS 2009 Asian report: Civic knowledge, attitudes, and engagement among lowersecondary students in five Asian countries. Retrieved from https://research.acer. edu.au/civics/17

Alam, B. (2014). Antropologi dan civil society: Pendekatan teori kebudayaan. 
Antropologi Indonesia, 30(2), 193-200. https://doi.org/10.7454/ai.v30i2.3564

Branson, M. S. (Ed.), Syarifudin, S. (Trans.). (1999). Belajar civic education dari Amerika. Yogyakarta: Lembaga Kajian Islam dan Sosial (LKIS).

Budimansyah, D. (2010). Pembelajaran pendidikan kesadaran kewarganegaraan multidimensional. Bandung: Genesindo.

Creswell, J. W. (2015). Penelitian kualitatif \& desain riset: Memilih di antara lima pendekatan (A. L. Lazuardi, Trans.). London: SAGE Publications.

Creswell, J. W. (2016). Research design: Pendekatan metode kualitatif, kuantitatif, dan campuran (A. Fawaid \& R. K. Pancasari, Trans.). London: SAGE Publications.

Ernawati, E., Tsurayya, H., \& Ghani, A. R. A. (2019). Multiple intelligence assessment in teaching English for young learners. REiD (Research and Evaluation in Education), 5(1), 21-29. https://doi.org/ 10.21831/reid.v5i1.23376

Feriandi, Y. A., \& Harmawati, Y. (2018). Analisis penguasaan kompetensi kewarganegaraan pada mahasiswa PPKn Universitas PGRI Madiun. Jurnal Citizenship: Media Publikasi Pendidikan Pancasila Dan Kewarganegaraan, 1(2), 7683. https://doi.org/10.12928/citizen ship.v1i2.13620

Galston, W. A. (2007). Civic knowledge, civic education, and civic engagement: A summary of recent research. International Journal of Public Administration, 30(6-7), 623-642.

https://doi.org/10.1080/01900690701 215888

Jb, M. C., \& Darmawan, L. (2016). Wacana civil society (masyarakat madani) di Indonesia. Jurnal Sosiologi Reflektif, 10(2), 35-64. https://doi.org/10.14421/jsr. v10i2.1157

Law No. 12 of 2012 of Republic of Indonesia on Higher Education. , (2012).
Miles, M. B., \& Huberman, M. (1994). Qualitative data analysis: An expanded sourcebook (2nd ed.). Thousand Oaks, CA: SAGE Publications.

Print, M., Ellickson-Brown, J., \& Baginda, A. R. (Eds.). (1999). Civic education for civil society. London: ASEAN [Association of South East Asian Nations] Academic Press.

Quigley, C. N., Buchanan Jr., J. H., \& Bahmueller, C. F. (1991). CIVTTAS: A framework for civic education. Calabasas, CA: Center for Civic Education.

Rosnawati, R., Kartowagiran, B., \& Jailani, J. (2015). A formative assessment model of critical thinking in mathematics learning in junior high school. REiD (Research and Evaluation in Education), 1(2), 186-198. https://doi.org/10. 21831/reid.v1i2.6472

Setiawan, A., \& Suardiman, S. P. (2018). Assessment of the social attitude of primary school students. REiD (Research and Evaluation in Education), 4(1), 12-21. https://doi.org/10.21831/reid.v4i1.192 84

Somantri, M. N. (2001). Menggagas pembaharuan pendidikan IPS. Bandung: Remaja Rosdakarya.

Sunarso, S., Sartono, K. E., Dwikusrahmadi, S., \& Sutarini, Y. C. N. (2016). Pendidikan Kewarganegaraan: PKn untuke Perguruan Tinggi. Yogyakarta: UNY Press.

Wardhani, C. M. (2019). Operasi Keselamatan Progo, Polresta Yogya tilang 977 pelanggar, 327 merupakan pelajar dan mahasiswa (A. Nugroho, Ed.). Retrieved from Tribun Jogja website: https://jogja.tribunnews.com/2019/05 /13/operasi-keselamatan-progo-polres ta-yogya-tilang-977-pelanggar-327-meru pakan-pelajar-dan-mahasiswa

Winarno, W. (2013). Pembelajaran pendidikan kewarganegaraan: Isi, strategi, dan penilaian. Jakarta: Bumi Aksara. 